\title{
Игнатьева К.С. \\ Деятельность органов исполнительной полиции Российской Империи в 1862-1905 гг. По противодействию и профилактике преступлений
}

Ульяновский государственнылй университет

(Россия, Ульяновск)

doi:10.18411/spc-20-11-2017-04

idsp: 000001:spc-20-11-2017-04

\section{Аннотация}

Данная статья подготовлена с целью анализа нормативно-правового обеспечения деятельности органов исполнительной полиции Российской империи во второй половине XIX в. - начале XX в. по противодействию и профилактике преступлений и иных видов правонарушений. Автор статьи, понимая актуальность данной темы в современных условиях, приходит к выводу, что органы исполнительной (общей) полиции Российской империи в исследуемый период - 1862 по 1905 годы выполняли помимо непосредственно правоохранительных функций, традиционно возлагаемых на органы полиции, и функции иных правоохранительных органов: суда, следственных органов, прокуратуры, и других.

Ключевые слова: полиция, Российская империя, общая (исполнительная) полиция, правоохранительные функции, Устав уголовного судопроизводства 1864 г., дознание, предварительное следствие, следственные мероприятия, оперативнорозыскные мероприятия.

\section{Abstract}

This article prepared for the purpose of analysis of normative-legal support of activity of bodies of Executive police of the Russian Empire in the second half of the XIX century beginning XX century for combating and prevention of crimes and other offences. The author, realizing the importance of this subject in modern conditions, comes to the conclusion that the Executive (General) of police of the Russian Empire during the study period 1862 to 1905 performed in addition to direct law enforcement functions traditionally assigned to police functions and other law enforcement agencies: the court, investigative bodies, prosecutors, and others.

Key words: police of the Russian Empire, the General (Executive) police, law enforcement functions, the Charter of criminal proceedings of 1864 , the inquiry, preliminary investigation, investigative actions, operational-investigative activities.

Органы исполнительной полиции как правоохранительные органы Российской империи были уполномочены по ее законодательству периода 1862-1905 годов на осуществление ряда важнейших функций как в целом по защите прав и законных интересов подданных на местах, так и по пресечению (профилактике) и предупреждению преступлений, иных видов правонарушений.

В примечании к ст. 1 Устава уголовного судопроизводства от 20 ноября 1864 г. [1] указывалось, что полицейские власти для предупреждения и пресечения преступлений, а также проступков, вправе применять меры, которые не относятся к мерам судебного преследования. В ст. 1 Свода Уставов о предупреждении и пресечении преступлений [2], изданном в 1890 году, говорилось, что местная полиция обязана предупреждать и пресекать нарушения, проявляющиеся в неуважении к вере, нарушении общественного спокойствия, порядка, благочиния, безопасности, личной безопасности имущества.

Анализ норм Устава уголовного судопроизводства показывает, что органы исполнительной полиции, точнее, органы местной полиции, с учетом их 
территориальной подведомственности в сфере противодействия преступности были уполномочены на:

- поддержание перед судом государственного обвинения по уголовным делам, подведомственным мировым судебным установлениям (ст. 3);

- выявление преступлений и сообщение об их совершении мировому судье (ч. 1 ст. 49, ст. 306);

- собирание по поручению мирового судьи всех необходимых по уголовному делу публичного обвинения юридических фактов (сведений) (ст. 47, 74), а по уголовному делу независимо от вида обвинения при наличии прямого обвинения против какого-то лиц - опрос объявителя (жалобщика) об обстоятельствах происшествия, признаках преступления (ст. 307);

- розыск лиц, совершивших преступные деяния и причинивших в результате их совершения вред и убытки, и предоставление сведений об этом мировому судье (ст. 48);

- сообщение мировому судье о совершенных преступлениях и иных правонарушениях, не относящихся к делам частного обвинения (ст. 49);

- «предварительное розыскание», то есть предварительное следствие подсудным мировым судьям (ст. 52);

- содействие судебным следователям в производстве предварительного следствия по уголовным делам, подсудным окружным судам (ст. 249);

- производство дознания по происшествиям о совершении преступлений и проступков, которые были выявлены полицией и при отсутствии ответа на сообщение полиции об этом со стороны судебного следователя, прокурора или его товарища (ст. 252), а также проведение по ним первичных следственных и оперативно-розыскных мероприятий по установлению признаков и состава преступления, проступка (ст. 253);

- осмотры, освидетельствования и обыски по особому поручению мирового судье, который не может их осуществить сам, данного местной полиции и обязанной оцеплять места обысков, обеспечивать сохранность вещественных доказательств (ст.ст. 105, 106, 365, 373, 1144);

- исполнительное производство по делам о денежных взысканиях или вознаграждениях, неуплаченных в установленный срок (ст. 189), делам о нарушениях Устава о паспортах [3] (ст. 1220), делам об уплате взысканий по Уставу путей сообщения [4](ст. 1231), и др.;

- этапирование осужденных к заключению в тюрьме до места исполнения уголовного наказания, надзор за осужденными (ст.ст. 191, 950, 971, 972), и другие.

Самим же органам полиции также должна была передаваться информация о совершении преступлений, особенно, содержащих признаки государственных преступлений (ст. 1035 Устава уголовного судопроизводства). Также Устав уголовного судопроизводства 1864 г. определял самостоятельные действия полиции в доставлении «повестки» о вызове, приводе в суд в случае уклонения обвиняемого, фиксации на здании полицейского управления неврученной по каким-то веским причинам повестки (ст.ст. 56, 380, 384, 385, 394), доставлении обвиняемого к следствию (ст. 394), составлении протокола о задержании обвиняемого (в том числе военнослужащего) с указанием причин задержания (ст.ст. 400, 1239), получении объяснений от обвиняемого (ст. 401), освобождении с указанием причин незаконного задержанного обвиняемого (ст. 402), и другие.

Согласно Уставу уголовного судопроизводства органы исполнительной полиции могли и самостоятельно напрямую участвовать в судебно-следственной деятельности с 
соблюдением требований о производстве предварительного расследования [5, с. 42]. Это регламентировалось ст. 48, 49, 250 - 261, 483, 965, 971 указанного уголовнопроцессуального закона.

В правовой литературе с мнением, что полиция выполняла функции следственных органов, согласны многие исследователи. В.В. Фролов отмечал, что уездные исправники и полицмейстеры, их помощники, иные полицейские чиновники общей полиции обязаны были содействовать в проведении расследований [6, с. 26-27].

Со своей стороны добавим, что, несмотря на официальное изъятие по реформе 1862 г. функций следствия из компетенции органов исполнительной полиции, они продолжали выполнять функции следственных органов и, отчасти, прокуратуры и суда. Если детально проанализировать нормы уголовно-процессуального закона Российской империи, действовавшего во второй половине XIX - начале XX вв., то можно удостовериться, что полиция не только должна была и всячески, оперативно, не превышая возложенные на них полномочия, содействовать следствию и лицам прокурорского надзора в осуществлении следственных действий по раскрытию преступления, но и сама осуществлять ряд судебно-следственных мероприятий и функций прокуратуры.

К числе правоохранительных функций можно было отнести такой вид деятельности органов исполнительной полиции Российской империи периода 1862 1905 гг. как противодействие терроризму, борьба с ним. Однако, как верно пишет А.В. Филонов, «незавершенность кодификации действующего законодательства Российской империи конца XIX - начала XX в. не дала возможности нормативно закрепить наиболее эффективную систему и структуру полиции, жандармерии и специальных служб Российской империи по борьбе с терроризмом, которая отвечала бы условиям рассматриваемого исторического периода» [7, с. 34].

Органы полиции Российской империи периода 1862-1905 гг. были уполномочены осуществлять, как мы указывали ранее, и профилактику в сфере совершения преступлений, иных видов правонарушений. Такой вывод можно сделать из анализа норм ст.ст. 1029-1155 отд. второго главы первой раздела четвертого «О судопроизводстве по преступлениям и проступкам, относящимся до разных частей административного управления» Устава уголовного судопроизводства. Так, согласно ст.ст. 1129, 1132, 1133, 1145, 1146, 1148, 1151, 1165, 1166 этого нормативного правового акта органы общей полиции (городская или земская полиции в зависимости от территориальной подведомственности) обязаны были, как контролировать соблюдение корпоративного, таможенного, лесного (в частности, Устава лесного [8]), жилищного и иного законодательства, так и возбуждать уголовные и административные дела о нарушениях частными лицами уставов казенного управления, нарушениях Устава таможенного [9], осуществлять по ним, а также по иным делам (например, по делам о нарушениях Устава питейного [10]), предварительное расследование, оперативно-следственные мероприятия. Например, по ст. 1173 Устава уголовного судопроизводства, в полицию могли быть переданы на сохранное хранение задержанные по уголовному делу товары, доставлены лица, незаконно провозившие товары, а затем полиция, при невозможности выполнить соответствующие оперативно-следственные действия мировым судьей или судебным следователем, обязана была составить протокол о задержании товара и подозреваемого лица, принять надлежащие меры к пресечению способов уклониться подозреваемому от следствия и суда.

Таким образом, полномочия органов исполнительной полиции Российской империи в рассматриваемый период в сфере противодействия и профилактики преступлений устанавливались Уставом уголовного судопроизводства от 20 ноября 1864 г. Данный кодифицированный акт уголовно-процессуального законодательства существенно конкретизировал обязанности и полномочия органов исполнительной 
полиции в области предварительного следствия, дознания и других процессуальных действий, но в тоже время наложил на них не свойственные им функции, входящие в круг полномочий суда, следствия, прокуратуры.

$$
* * *
$$

1. Устав уголовного судопроизводства (прин. 20 ноября 1864 г.) [Электронный ресурс]. - Режим доступа: Справочная правовая система «Гарант»: http://constitution.garant.ru/history/act16001918/3137 (дата обращения: 08.11.2017 г.).

2. Свод Уставов о предупреждении и пресечении преступлений (Изд. 1890 г.) // Собрание законов Российской империи. T. 14 [Электронный pecypc]. - Режим доступа: http://www.russky.com/history/library/vol.14/vol.14.3.htm (дата обращения: 08.11.2017 г.).

3. Уставы о Паспортах и Беглых // Свод законов Российской империи. Изд. 1857 г. Т. 14. - СПб., 1857. [Электронный ресурс]. http://www.runivers.ru/bookreader/book388229/\#page/9/mode/1up (дата обращения: 07.11.2017 г.).

4. Уставы Путей Сообщения// Свод Учреждений и Уставов Путей Сообщения. Свод законов Российской империи. Изд. 1857 г. Т. 12. - СПб., 1857. [Электронный ресурс]. - Режим доступа: http://www.runivers.ru/upload/iblock/e0c/12-1.pdf (дата обращения: 07.11.2017 г.).

5. Седунов, А.В. Российская полиция во второй половине 19 - начале 20 века: сфера компетенции, отношение к службе, реформирование / A.В. Седунов // История государства и права. - 2005. - № 3. - С. 41-43.

6. Фролов, В.В. Изменение правоохранительной системы в России во второй половине 19 века / В.В. Фролов // История государства и права. - 2006. - № 7. - С. 26-27.

7. Филонов А.В. Опыт деятельности полиции, жандармерии и специальных служб Российской империи как органов по борьбе с терроризмом. Конец XIX - начало XX в. / А.В. Филонов // Закон и право. - 2013. - № 2. - С. 33-35.

8. Устав Лесной (Свод учреждений и уставов лесных 1802 г., в ред. 1835, 1842 гг.). Ч. 1. Т. 8. Свод законов Российской империи (изд. 1857 г.). - СПб., 1857 [Электронный ресурс]. - Режим доступа: http://www.runivers.ru/bookreader/book388190/\#page/3/mode/1up (дата обращения: 07.11.2017 г.).

9. Уставы Таможенные (Устав Таможенный по Европейской торговле, Устав Таможенный по Азиатской торговле, прин. 14 декабря 1819 г., вст. в дейст. 1 января 1820 г.) // Свод законов Российской Империи. Собрание III: В 15 тт. - СПб., 1857. - 563 с. [Электронный ресурс]. - Режим доступа: http://www.runivers.ru/bookreader/book388160/\#page/6/mode/1up (дата обращения: 07.11.2017 г.).

10. Уставы о податях, о пошлинах и о сборах с питей, с свекло-сахарного производства и с табаку // Свод законов Российской империи. Изд. 1857 г. Т. 5. - СПб., 1857. [Электронный ресурс]. - Режим доступа: http://www.runivers.ru/bookreader/book388158/\#page/1/mode/1up (дата обращения: 07.11.2017 г.).

\section{Комбарова Е.Л. \\ Судебные версии как инструмент уголовно-процессуального познания судьи}

Российский государственный университет правосудия, Центральный филиал (Россия, Воронеж)

doi:10.18411/spc-20-11-2017-05

idsp: 000001:spc-20-11-2017-05

В настоящее время учение о криминалистической версии представляет собой сформированную целостную теорию, в рамках которой исследователи пришли к достаточно единообразной трактовке понятия криминалистической версии, особенностей выдвижения версий и их проверки.

Под криминалистической версией понимается логически обоснованное, базирующееся на фактических данных предположение субъектов, осуществляющих уголовно-процессуальное познание, о сути исследуемого деяния, его отдельных фактах и обстоятельствах в целях установления истины [1].

К числу субъектов, выдвигающих криминалистические версии, подавляющее большинство исследователей относят оперативно-розыскного работника, эксперта, следователя (дознавателя), прокурора и суд.

Однако весьма дискуссионной является роль суда как субъекта криминалистической тактики, формирующего и проверяющего криминалистические версии, что обусловлено спецификой современной законодательной регламентации 